\title{
Türkiye-Irak Kürt Bölgesel Yönetimi (IKBY) İlişkilerinde Güvenliksizleştirmeler: 2008-2016 Arası Dönem *
}

\author{
Muhsin BARAN ** \\ Muzaffer Ercan YILMAZ ${ }^{* * *}$
}

Öz

Türkiye, inşa ettiği kimlik ve ulus devlet anlayışına potansiyel tehdit ürettiği gerekçesiyle Irak Kürt bölgesiyle olan ilişkilerinde cumhuriyetin kuruluşundan itibaren güvenlik odaklı bir ilişki biçimi benimsemiştir. 1980'lerde PKK’nın Irak’ın kuzeyine yerleşerek Türkiye'ye saldırılar gerçekleştirmesi ve daha sonraki süreçlerde Ortadoğu bölgesindeki savaş ya da iç savaşlar nedeniyle meydana gelen ciddi değişimlerin Irak’ın kuzeyine yansımaları sonucu ortaya çıan yapıların Türkiye’ye varoluşsal bir tehdit unsuru olarak değerlendirilmesi, ilişkilerin tarihsel olarak güvenlikleştirilmesinin en önemli nedenleri olmuştur. Bununla birlikte, uzun yıllardır süregelen güvenlik odaklı ilişki biçimine 2000'li yılların ikinci yarısından itibaren son verilmiştir. Bu bağlamda, Türkiye Irak Kürt Bölgesel Yönetimi ilişkilerinde, 2008-2016 arası dönemde, ciddi değişimler görülmüştür. İlişkilerde meydana gelen bu paradigma değişikliği ile birlikte daha önce "güvenlik" konusu olarak değerlendirilen birçok konu ya da sorun siyaset alanına taşınarak güvenliksizleştirilmiştir. Yüksek düzeyli temaslar, enerji alanındaki işbirliği, IŞక̇D’e karşı mücadele ve eğitim alanındaki işbirliği söz konusu dönemdeki güvenliksizleştirmelerin ana temasını oluşturan başlıca unsurlar olmuştur.

Anahtar Kelimeler: Güvenlikleştirme, Varoluşsal Tehdit, Irak Kürt Bölgesel Yönetimi, Güvenliksizleştirme.

\footnotetext{
* Bu çalışma, Muhsin Baran tarafından Muzaffer Ercan Yılmaz danışmanlığında Ağustos-2017’de Uludağ Üniversitesi Sosyal Bilimler Enstitüsü’ne sunulan "Türkiye-Irak Kürt Bölgesel Yönetimi İlişkilerinin Güvenlikleştirme ve Güvenliksizleştirme Süreçlerinin Analizi” adlı doktora tezinden türetilmiştir.

** Öğr. Gör. Dr., Bandırma Onyedi Eylül Üniversitesi, mbaran@bandirma.edu.tr

(C) Sorumlu yazar/Corresponding author

*** Prof. Dr., Bursa Uludağ Üniversitesi, İktisadi ve İdari Bilimler Fakültesi, Uluslararası İlişkiler Bölümü, muzaffer_ercan@yahoo.com
} 


\title{
Desecuritizations in the Relations of Turkey and Iraqi Kurdish Regional Government (IKRG): Years between 2008 and 2016
}

\begin{abstract}
Turkey has adopted a kind of security based relationship with Iraqi Kurdish region since the establishment of the republic as this region was thought to be generating a potential threat to the constructed identity and the established nation state. The attacks of the PKK from the northern Iraq starting from 1980s and later on the emergence of some entities posing existential threat to Turkey in this region as a result of wars or civil wars in the Middle East were the main reasons for the securitization of the relations between Turkey and Iraqi Kurdish region. However, starting from mid-2000s, this security-based relationship was concluded. In this respect, there were great changes in the relations of Turkey and Iraqi Kurdish Regional Government between 2008-2016. In parallel with this paradigm shift in the relations, several issues were taken out from the security field and they were started to be discussed in the field of politics. That's, these issues were desecuritized. High-level meetings, cooperation in the field of energy, the common struggle against the ISIS and the cooperation in the field of education were the main components of the desecuritization in this period.
\end{abstract}

Keywords: Securitization, Existential Threat, Iraqi Kurdish Regional Government, Desecuritization.

\section{GİRIŞ}

Türkiye 1920'li yılların ortalarından başlayarak 1980'lı yılların başlarına kadar olan dönemde Irak’ın kuzeyinden kaynaklı tehditleri önemli bir güvenlik sorunu olarak algılamıştır. Bu algı paralelinde söz konusu bölgeye yönelik güvenlik odaklı politikalar izlemiştir. Musul sorununun çözüme kavuşturulmasıyla izlenen bu politika, Irak’n kuzeyinden kaynaklı tehditleri bertaraf etmek bağlamında ağırlıklı olarak güvenlik bürokrasisi tarafından şekillendirilmiş ve siyasi liderlerce de uygulanmıştır. Bölgedeki unsurlardan gelebilecek tehdit Irak devletiyle yapılan anlaşmalar ve yine Irak devletinin bağıtlı olduğu çeşitli uluslararası angajmanlarla minimize edilmeye ya da ortadan kaldırılmaya çalışılmıştır.

Türkiye’nin bölgeye yönelik olarak 1980’lerin başlarına kadar izlediği güvenlik odaklı politikalar bazı dönemlerde bürokratik uygulamalar ve söz edimleri ile güvenlikleştirilmiştir. Özellikle, 1980'lerin başlarından itibaren PKK’nın bölgede konuşlanması ve örgütün farklı dönemlerde bölgedeki Kürt unsurlarla işbirliği yapması, 
bu bölgenin ve bölgedeki gelişmelerin çoğu zaman Türkiye için varoluşsal bir tehdit olarak etiketlenmesine ve Türkiye’nin bu bölgeyle ilişkilerini güvenlik kaygılarını ön plana çıaran bir politika kapsamında yürütmesine neden olmuştur.

1990’ların başlarında Körfez Savaşının hemen sonrasında bölgede Çekiç Güç’ün sağladığ1 güvenlikli ortamdan yararlanan Iraklı Kürt grupların federe devlet kurma çabaları benzer biçimde Türkiye tarafından kaygıyla ve yakından izlenmiştir. Bu dönemde, Türkiye’nin Kuzey Irak bölgesine angajmanı büyük ölçüde PKK’nın bu bölgeden ürettiği güvenlik risklerini minimize etme ve bölgede Türkiye’nin güvenliğini tehdit edebilecek potansiyel oluşumları bertaraf etme nedenlerinden kaynaklanmıştır.

2000'li yılların başında ABD’nin Irak’ı işgali sonrasında Irak'ın yeniden yapılandırılması sürecinde Irak'ın kuzeyindeki de facto oluşumun hukuki bir nitelik kazanarak yarı bağımsız bir entiteye dönüştürülmesi Türkiye tarafından dikkatle izlenmiştir. Türkiye, artık hukuki bir nitelik taşıyan bu oluşumun Irak’tan tüm bağlarını kopararak bağımsız bir yapıya dönüşmemesi için bu bölgeyle güvenlik kaygıları temelinde kontrollü bir ilişki biçimi geliştirmiştir. Bu dönemde Iraklı Kürt gruplara sık aralıklarla bağımsız bir devlet gibi değil, "Iraklılık" kimliği doğrultusunda davranmaları gerektiği yönünde uyarılarda bulunulmuştur. Fakat, takip eden süreçte, 2008 yılından başlayarak Irak’’n kuzeyindeki Kürt gruplarla tarihsel olarak güvenlik kaygıları temelinde yürütülen ilişki biçimine son verilmiş ve yeni bir politikayla söz konusu gruplarla olan ilişkiler ağırlıklı olarak siyaset alanına çekilmiştir. Bu durum ilişkilerin güvenliksizleştirilmesi sonucunu ortaya çıkarmıştır.

Ortaya çıkan bu yeni durum paralelinde ilgili dönemde iki birim arasındaki ilişkilere ivme kazandıran unsurların neler olduğu ve güvenliksizleştirmelere hangi boyutta ve nasıl katkıda bulundukları bu çalışmanın odaklandığı ve cevap aradığı temel sorulardır. $\mathrm{Bu}$ dönemde, elitlerin sivil siyasetin egemen olduğu politik atmosferde iç ve diş siyasi konjonktürlere bağlı olarak geliştirdiği politikalar Türkiye ile IKBY arasındaki ilişkilerin güvenliksizleştirilmesinde önemli bir rol oynamıştır. Bununla birlikte, başta enerji olmak üzere farklı alanlarda yapılan işbirliğinin güvenliksizleştirmelere katkısı vardır.

Türkiye-IKBY ilişkilerindeki güvenliksizleştirmeleri içeren bu çalışma 3 bölümden oluşmaktadır. Birinci bölüm, bu çalışmanın teorik çerçevesini çizen Kopenhag Okulunun Güvenlikleştirme Teorisini konu alacaktır. İkinci bölüm, Türkiye-IKBY ilişkilerindeki güvenliksizleştirmeleri sektörel olarak ele alacak ve analiz edecektir. Makale, güvenliksizleştirmelerin 2008-2016 arası dönemde ilişkilerde meydana getirdiği dönüşümü özetleyen bir sonuç bölümüyle sona erdirilecektir.

\section{GÜVENLIKLEŞTİRME (SECURITIZATION) TEORİSİ}

Kopenhag Okulunun akademik literatürde en öne çıkan yaklaşımı olan Güvenlikleştirme Teorisi, bir siyasi toplulukta değer atfedilen bir nesneye (referans nesnesi) yönelik herhangi bir durumu varoluşsal bir tehdit olarak gösteren ve bu tehdidi bertaraf etmek için acil ve 
olağandışı tedbirlerin gereğine söylemlerle vurgu yapan öznelerarası bir anlayışın inşa edildiği diskursif bir süreç olarak tanımlanmaktadır (Buzan ve Waever, 2003: 491).

Güvenlikleştirme, siyaseti yerleşik kuralların ötesine taşıyarak konuyla ya siyasetin özel bir biçimini kullanarak ilgilenme ya da siyaset üstü bir yerde konumlandırma ile gerçekleşir. Teorik olarak, kamuyu ilgilendiren bir konu bir spektrumda dizilmiş gibi üç kategoriden birinde yer alır. Birincisi, siyasi olmayan kategoridir. Bu bölümdeki bir konu devletin ilgi alanına girmez ve kamuoyu tartışmaları ve kararlarıyla ilgili değildir. İkinci kategori, siyasi olandır. Bu kategoriye giren konular kamu siyasasını ve müdahalesini kısmen gerektirir. Üçüncü ve son kategori, güvenlikleştirilen konuların bulunduğu alandır. Bu alandaki bir konu, varoluşsal bir tehdit olarak sunulur ve sorunun çözümü için normal siyasetin dışında acil önlemler almayı gerektirir (Buzan vd., 1998: 23-24).

Bir konunun normal siyaset alanının dışına çıkartılarak güvenlikleştirilmesi için, sorunun objektif anlamda varoluşsal bir tehdit olmasına gerek olmayıp bu şekilde sunulması yeterlidir (Buzan vd., 1998: 24). Bir başka deyişle, Kopenhag Okulu için nesnel tehditlerden değil meseleleri güvenlik alanına havale eden tehdit temsillerinden söz edilebilir (Kaliber, 2005: 36). Burada tehditler ve güvenlik objektif konular değildir, güvenlik bir sorunu etiketleme ve ele alma biçimidir (Waever, 1996: 108). Fakat varoluşsal tehdidin subjektif olduğunu söylemek de yetersiz kalır. Çünkü bir konunun güvenlik konusu olduğuna sadece bireyler karar vermez ve burada [asıl olan] güvenlikleştirmenin öznelerarası ve toplumsal olarak inşa edildiğidir(Buzan vd., 1998: 31). Bir konunun güvenlik problemi olduğu ancak toplumdaki elitlerin kabulü ile mümkündür (Waever, 1998: 44). Bu konunun başarılı bir şekilde güvenlikleştirilmesi için alımlayıcı kitle (audience) tarafından onaylanması gerekir. Alımlayıcı kitlenin kabulü hem rıza hem de baskı yoluyla gerçekleşebilir. Eğer konunun güvenlik sorunu olduğu alımlayıcı kitle tarafından kabul edilmezse, güvenlikleştirmeden değil bir güvenlikleştirme hamlesinden (securitization move) bahsedilebilir (Buzan vd., 1998: 25). Yani, güvenlikleştirmenin başarılı olması için konuyu yerleşik siyasi kuralların ötesinde, siyasetin özel bir biçimiyle ya da siyaset üstü bir biçimde ele almak için belli oranda bir desteğe gereksinim vardır (Wilkinson, 2007: 9).

Güvenlikleştirme Teorisi, birbirinin içine geçmiş iki mantığa vurgu yapmaktadır. Bunlar: varoluşsal tehdit iddiaları ve olağandışı tedbirlerin meşruiyetidir. Güvenlikleştirme süreci ile belli bir güvenlik konusunun diğerlerine göre daha fazla öncelik gerektirdiği iddia edilir. Bu yüzden, güvenlikleştirici aktör olağandışı önlemler kullanarak konuyu ele almak konusunda özel imtiyaz kullanmak ister. Güvenlikleştirme çatışmacı bir zihniyetle sonuçlanır. Bu yüzden, sıradan siyasi prosedürler savaş durumu ya da acil durumlarda uygulanmadığından dolayı ve varoluşsal tehditlere verilen tepkiler standart siyasi uygulamalar dışında olduğu için, bir konuyu varoluşsal bir tehdit olarak etiketlemek normal politikanın dışına çıkıp acil durumlarda uygulanacak politikalara geçişi gerektirir (Coşkun, 2011: 9).

Söz konusu geçişin tamamlanıp güvenlikleştirmenin tam anlamıyla gerçekleşmesi için alınacak önlemlere meşruiyet kazandırılması gerekmektedir (Buzan vd., 1998: 25). 
Meşruiyetin sağlanması, güvenlikleştirici aktörün (securitizing actor) konuşma edimi (speech act) yardımıyla alımlayıcı kitleyi (audience) varoluşsal tehdidin (existential threat) referans nesnesini (referent object) tehdit ettiği ve buna bağlı olarak alınması gereken istisnai önlemler konusunda ikna etmesi ile gerçekleşir. Alımlayıcı kitleden alınacak onay zor yoluyla ya da rıza ile gerçekleşebileceği gibi, bazen yasal yaptırımlarla kitlenin sessiz kalması sağlanarak da alındığına dair görüşler mevcuttur (Kaliber, 2005: 38). İknaya yönelik güvenlikleştirici aktör ve alımlayıcı kitle arasındaki etkileşim sürecinde mevcut gerçeklerin varoluşsal anlamda bir tehdit olduğu algısı yerleşirse, konu güvenlik gündemine girer ve bunun sonucunda güvenlik politikaları oluşturulur (Oelsener, 2005: 3).

Güvenlikleştirme Teorisinin önemli bir unsuru da Güvenliksizleştirmedir. (Desecuritization). Güvenliksizleştirme, bir konuya güvenlikleştirme sürecinde güvenlik kaygıları bağlamında atfedilen anlamın ortadan kalkması ve konunun normal siyaset alanına sokulması ile gerçekleşir. Başka bir ifadeyle güvenliksizleştirme, siyasal bir topluluğun bir konuyu değer atfedilen bir referans nesnesine varoluşsal bir tehdit olarak sunmaması ve bu tehditle başa çıkmak için acil ve istisnai tedbirler alınması gerektiğine dair çağrılarda bulunmamasıdır. Bu süreç, doğrudan eskiden tehdit olarak sunulan konunun artık bir tehdit olmadığına dair bir söylemle ya da daha sıklıkla, endirekt bir şekilde, başka konulara yönelerek daha önce güvenlikleştirilen konuların daha az dikkat çekmesini sağlama biçiminde gerçekleşir (Buzan ve Waever, 2003: 489).

Güvenliksizleştirme süreci, güvenlikleştirmeye bir tür karşı çıkış ya da direniş olarak algılanabilir. Güvenlikleştirme, bir politikanın kullandığg bir taktik olarak düşünülürse, güvenliksizleştirme de bu taktiklere karşı bir harekattır (Vuori, 2011:7). Bu karşı hamle başarılı olursa, güvenliksizleştirme süreci başarıyla tamamlanmış olur. Örneğin toplumsal sektörde başarılı bir güvenliksizleştirme, iki farklı kimliğin aynı anda var olabileceğine dair bir kabulle gerçekleşebilir (Coşkun, 2008: 394).

Konular güvenliksizleştirme sürecinde güvenlik alanından çıkarılır. (Waever, 1998:46). Daha önce güvenlik gündemine girmiş konular gündemde işgal ettikleri yeri kaybeder, meşrulaştırılan istisnai tedbirler tedricen kaldırılarak şiddet meşru bir seçenek olmaktan çıkarılır (Coşkun, 2011: 18). Bu süreçle nihai olarak hedeflenen pozitif barıştır. Oelsener, güvenliksizleştirmeyi bu hedefe giden yolda ikinci eşik olarak tanımlar. Buna göre ilk basamak güvenliğin veya güvenlik kaygılarının hakim olduğu dönem, ikinci aşama güvenliksizleştirme, üçüncü aşama ise güvenlik kaygılarının olmadığı süreçtir (Oelsener, 2005: 1).

Oelsener'in nihai hedef olarak pozitif barışa giden sürecin önemli bir aşaması olarak sunduğu güvenliksizleştirme süreci iki şekilde gerçekleşir. Birinci seçenekte, daha önce güvenlik kaygılarının öne çıkmasına neden olan ve istisnai tedbirler alınması yönünde alımlayıcı kitleyi ikna etmiş olan güvenlikleştirici aktör, tehdidin doğasında değişiklik algılar ve bunun artık tehdit edici özelliğini kaybettiğini düşünür. Diğer seçenekte ise, güvenlik söyleminde bulunan aktör ve alımlayıcı kitle, tehdit edici şey ile kendi aralarındaki ilişkide niteliksel bir değişiklik algılar ( örneğin, bir konu tehdit edici dahi 
olsa artık kendilerini tehdit etmediğine olan inançları) (Oelsener, 2005: 4).

Waever’a göre Kopenhag Okulu, konuların güvenliksizleştirilmesi bağlamında siyaset yapıcılara üç yol belirlemiştir. Buna göre güvenliksizleştirme sağlama da takip edilecek yöntemler şunlardır: Daha önce güvenlikleştirilen konular hakkında konuşmama, güvenlik ikilemleri ya da kısır döngüler oluşturmama ve güvenlik konularını siyaset alanına taşıma (Coşkun, 2011: 19).

Waever'ın güvenlikleştirme teorisine önemli eleştiriler getiren Hansen, güvenliksizleştirmenin dört biçimde gerçekleştiğini belirtmiştir. Buna göre güvenliksizleştirme; istikrar yoluyla bir değişimle, güvenlik alanından çıkarılan bir konunun yerine başka konular yerleştirerek, tehditlere ve tehlikelere karşı politik bir çözüm sunup konuları güvenlik gündeminden çıkararak ve sessiz kalınarak gerçekleştirilir (Hansen, 2012: 539-544).

Kısacası, Güvenliksizleştirme Yaklaşımı, konuların güvenlik ve güvenlikleștirme gündeminden çıarılması olarak tanımlanır (Williams, 1998: 438). Hansen'e göre, güvenlikleştirmenin tamamlayıcısıdır ve bu bağlamda, güvenlikleştirme güvenliksizleştirmeye bağımlıdır. Yani güvenlikleştirme analitik ve politik anlamını kazanmak için güvenliksizleştirmeye muhtaçtır (Hansen, 2012: 531).

Güvenliksizleştirme sürecinde güvenlikleştirmede olduğu gibi bir söz edimine gereksinim olup olmadığı konusu tartışmalıdır. Bu konuda farklı görüşler vardır. Aras ve Polat'a göre güvenliksizleştirmede güvenlikleştirmede olduğu gibi bir söz ediminin olmayışı güvenliksizleştirmeye katkıda bulunur (Aras ve Polat, 2008:499). Güvenliksizleştirme sürecinde bir aktörün "ben bu konunun artık tehdit olmadığını ilan ediyorum" türünden söylemi, güvenlik mantığına aykırıdır (Hansen, 2012: 539). Benzer bir şekilde, tersine güvenlikleştirmenin olduğu güvenliksizleştirme sürecinde, bir güvenliksizleştirici aktörün olup olmadığı konusu da tartışmalıdır. Güvenliksizleştirici aktör yerine sosyal aktör kavramını kullanan Oelsener, bu aktörlerin politika yapıcılar ve diğer ekonomik ve entelektüeller elitlerden oluşabileceğini ve gerçekle ilgili yeni oluşturdukları algılarını alımlayıcı kitleye ileterek geniş ölçüde meşrulaştırılmış somut politikaların oluşturulmasına katkıda bulunabileceklerini iddia eder (Oelsener, 2005: 15).

Güvenliksizleştirme süreci yukarıdan aşağıya olduğu gibi aşağıdan yukarıya doğru da olabilir. Bazı durumlarda süreçte dış gelişmelerin rolü olsa da, hem güvenlikleştirme hem de güvenliksizleştirme asıl olarak iç gelişmelerin ürünüdür (Coşkun, 2008: 394). Bu bağlamda, iç gelişmeler hem iç politika hem de diş politikadaki güvenliksizleştirme süreçlerini önemli oranda etkiler.

\section{IKBY İLE İLİŞKİLERDE GÜVENLİKSİZLEŞTIRMELER}

Irak’ın kuzeyinde kurulacak bağımsız bir Kürt oluşumunun Türkiye’nin birliğine, rejimine, inşa edilen kimliğe ve toprak bütünlüğüne varoluşsal tehditler oluşturacağı/ 
oluşturabileceği kaygısıyla Türkiye’nin tarihsel olarak güvenlik alanında yürüttügü ilişkilerin güvenliksizleştirilmesi, yani normal siyaset alanına taşınmasının ilk adımı 2008 yılında atılmıştır. Bu sürecin başlamasıyla birlikte ilişkiler daha sonraki yıllarda tedricen daha iyiye evrilmiştir.

Siyasi aktörlerin güvenlik bürokrasisinden daha etkili olduğu bu sürecin ancak 2000'li yılların ikinci yarısından sonra başlamasının ya da başlayabilmesinin nedeni bazı konjonktürel siyasi gerçeklerin önceki yıllarda Türk yöneticilere ve siyasilere isteseler dahi Iraklı Kürt gruplarla siyaset alanında normal ilişkiler kurma olanağı vermemesiydi. Fakat ilişkilerin ağırlıklı olarak güvenlik alanında sürdürüldügü 2000’li yılların başında bu bölgeyle kurulan temasların, daha sonraki süreçte tedricen normalleştirilen ilişkilere bir alt yapı hazırladı̆̆ı gerçeği de göz ardı edilmemelidir.

Siyasi aktörler 2008 yılından başlayarak, IKBY ile olan güvenliksizleştirme sürecini yürütürken farklı yöntemler kullanmışlardır. IKBY ile ilişkilerin normalleştirilmesi bağlamında kullanılan yöntemlerden bazıları şunlardır: eskiden varoluşsal tehdit olarak etiketlenen bazı konular hakkında konuşmayarak toplumun yani alımlayıcı kitlenin gündemine getirmemek, eskiden varoluşsal tehdit olarak görülen IKBY ile var olan ekonomik ilişkilere ivme kazandırarak bu alandaki olumlu ilişkilerin farklı alanlara da taşınmasını sağlamak, daha önceki söz edimleri neticesinde toplumda Türkiye’nin bekasına bir tehdit oluşturdukları yönünde algı oluşmuş bazı Iraklı Kürt liderlerle kamuoyu önünde üst düzey temaslar sağlayarak bu kişiler hakkında toplumda oluşmuş negatif algıları değiştirmek ve son olarak güvenlikleştirici politikalar sonucu toplumda kullanılması tabu haline gelmiş bazı kavramları kullanarak sorunların normalleşmesini ve toplumda tartışılmasını sağlamak.

Türk dış politikası karar alıcılarının IKBY’e yönelik güvenliksizleștirmeleri bu dönemde Türkiye ile ilgili sahip oldukları küresel ve bölgesel vizyonları ile de örtüşmekteydi. Türk dış politikasında yeni bir paradigma olarak nitelendirilebilecek bu vizyonun gerçekleşmesi bağlamında Türkiye'nin hem komşularıyla olan bazı uyuşmazlıklarını hem kendi iç sorunlarını çözmesi gerekliydi. "Restorasyon" olarak da adlandırılan yeni politik vizyon çerçevesinde eski Osmanlı İmparatorluğu topraklarında yaşayan etnik unsurlar arasında "kadim birliktelik"”ten doğan bir "tarihdaşlık" 'tan yola çıkılmış, Türkiye Cumhuriyeti’nin Osmanlı bakiyesi unsurlar arasında bir ayrımcılık yapmayacağı yaklaşımı esas alınmıştı (Davutoğlu, 2013). "Restorasyon” yaklaşımı ile ilişkilerin düzeltilmesi hedeflenen unsurlardan birisi de Iraklı Kürt gruplardı.

\subsection{Psikolojik Engelleri Yıkan Diplomatik İlișkiler}

Türkiye’nin Irak Kürt Bölgesel Yönetimi ile ilişkilerinin normalleşmesi sürecinde IKBY ile psikolojik engelleri yıkan ilk açık diplomatik ilişki 27 Şubat 2008 tarihinde kuruldu. Dönemin Başbakanlık Dışişleri Başdanışmanı Ahmet Davutoğlu ile Türkiye'nin Irak Özel Temsilcisi Murat Özçelik Bağdat'a giderek dönemin Irak’ın Kürt kökenli Dışişleri Bakanı Zebari ile görüştü. Bu ziyaretin hemen akabinde, dönemin Irak’ın Kürt kökenli 
Cumhurbaşkanı Celal Talabani, Mart 2008'de Ankara'ya davet edildi (Oran, 2013: 291). Böylece Irak Merkezi Yönetimi üzerinden de olsa Iraklı Kürt gruplarla açık ve aracısız siyasi temaslar sağlandı.

İlişkilerin normalleştirilmesi hedefiyle Irak Merkezi Yönetiminde yer alan Kürt kökenli devlet yetkilileriyle sağlanan temasları takiben Irak Kürt Bölgesel Yönetimi yetkilileriyle de diplomatik ilişki kurulmaya başlandı. Bu kapsamda, Davutoğlu ve Özçelik’in Mayıs 2008'de Bağdat'a giderek önce Talabani daha sonra da Bölgesel Yönetim Başbakanı Neçirvan Barzani ile ilk kez görüştü (Oran, 2013: 292). Bu durum, yeni yüksek düzeyli diplomatik görüşmelere kapı araladı. Takip eden süreçte, Türkiye’nin Irak Özel Temsilcisi Murat Özçelik, önce Ekim 2008'de, daha sonra da 11 Ocak 2009'da Irak Kürt Bölgesel Yönetimi Başkanı Mesut Barzani ile görüştü (Özpek, 2011: 592).

2009'daki ziyaret ve görüşmeler, diplomatik temasları ileri bir aşamaya taşıdı. Mart 2009'da Bağdat’a resmi bir ziyaret gerçekleştiren dönemin Cumhurbaşkanı Abdullah Gül, Irak Kürt Bölgesel Yönetimi Başbakanı Neçirvan Barzani ile de görüştü. Bu ziyaretten birkaç ay sonra, Ekim 2009'da, dönemin Başbakanı Tayyip Erdoğan Bağdat’a yaptığı bir çalışma ziyaretinde, Musul ve Basra ile birlikte Erbil'de de Türkiye Cumhuriyeti konsolosluğunun açılması kararının verildiğini açıkladı(Oran, 2013: 292). Takip eden süreçte, Türkiye ile Irak Kürt Bölgesel Yönetimi arasındaki diplomatik temasların doruk noktasına ulaştığını gösteren siyasal gelişmeler, dönemin Dışişleri Bakanı Davutoğlu’nın Haziran 2010'da, dönemin Başbakanı Erdoğan’ın da 2011'de Erbil ziyareti kapsamındaki görüşmeleriydi.

Siyasi yöneticilerin diplomatik ilişkiler bağlamında 2008 yılından başlayarak Iraklı Kürt unsurlarla tedricen geliştirdiği iyi ilişkilerin bir somut örneği olarak Iraklı Kürt liderlerle gerçekleştirdikleri üst düzey temasları halka ve medyaya açı platformlarda gerçekleștirmesi, Iraklı Kürt liderler hakkında Türkiye kamuoyunda eskiden var olan negatif algıların belli bir oranda değişmesine önemli katkıda bulunmuştur. Söz konusu temaslar ile bu liderler hakkında kamuoyunda var olan negatif algı azalmış ve güvenliksizleştirmeler belli bir düzeye kadar başarıya ulaşmıştır. Üst düzey temaslar, eskiden söz edimi yoluyla varoluşsal tehdit olarak etiketlenen Iraklı Kürt liderlerin Irak merkezi ve bölgesel yönetimlerindeki pozisyonları Türk kamuoyunda olağan ve meşru kabul edilmeye başlanmıştır. Türk kamuoyunun Kürt liderlere bakış açısının kurulan diplomatik ilişkilerle büyük ölçüde değişmesiyle, Türkiye ve IKBY arasındaki ilişkiler başka alanları da kapsamaya başlamıştır.

\subsection{Ekonomik İlişkiler}

Türkiye ile Irak Kürt Bölgesel Yönetimi arasında ağırlıklı olarak güvenlik konusuna endeksli ilişkilerin başka alanlara taşmasını sağlayan en önemli etken tersine güvenlikleştirmelere zemin hazırlama bağlamında katkıda bulunan karşılıklı ekonomik ilişkilerdir. 1990'ların başlarında başlayan ve tedricen geliştirilen ekonomik ilişkiler dönemsel olarak bazı olumsuzluklardan etkilense de, artan bir şekilde devam etmiş ve spill over bir etkiyle başka alanlarda da işbirliği yapılmasına olanak sağlamıştır. Ekonomik ilişkilerin yoğunlaştığ 
başlıca iki alan IKBY'deki Türk şirketlerinin yaptığı yatırımlar ve enerji konusu olmuştur.

Türkiye- IKBY arasındaki ekonomik ilişkilerin boyutu özellikle 2008 yılından başlayarak hızlı bir yükseliş trendine girmiştir. 2013 yılında, Türkiye ile Irak arasındaki yaklaşık 12 milyar dolarlık ticaret hacmi gerçekleştirilmiştir (Türkiye Cumhuriyeti Ekonomi Bakanlığ 1 , 2014). Söz konusu ticaretin 8 milyar dolarlık kısmı Türkiye ve Irak Kürt bölgesi arasında yapılmıştır (Abacıŏlu, 2014: 25). İhracat dengesinin mutlak anlamda Türkiye lehine olduğu bu rakamla birlikte Irak Kürt Bölgesel Yönetimi, Türkiye’nin Almanya'dan sonra en fazla ihracat yaptığı yer olmuştur. Bu trend sonraki yıllarda IŞíD (Irak-Şam İslam Devleti) saldırıları ve merkezi yönetimle yaşanan sorunlardan kaynaklı ekonomik krizlerden dolayı kısmen inişe geçse de, bu bölgeyle olan ticari ilişkiler, ikili ilişkilerde önemli bir yer tutmaya devam etmiştir.

Tablo 1: Yıllara Göre Türkiye’nin Irak’a İhracat Rakamları

\begin{tabular}{|l|l|}
\hline \multirow{2}{*}{2008} & Değer: Bin ABD Dollari \\
\hline 2009 & 3916685 \\
\hline 2010 & 5123406 \\
\hline 2011 & 6036362 \\
\hline 2012 & 8310130 \\
\hline 2013 & 10822144 \\
\hline 2014 & 11948905 \\
\hline 2015 & 10887826 \\
\hline 2016 & 8549967 \\
\hline
\end{tabular}

Kaynak: Türkiye İstatistik Kurumu, 2017

Özellikle 2010’lı yılların başında ekonomik ilişkilere ivme kazandıran başat unsur, normalleşen ilişkiler paralelinde Irak Kürt Bölgesel Yönetimi sınırları içinde birçok sektörde yatırım yapan Türk şirketleri olmuştur. Irak Kürt Bölgesel Yönetiminin sağladığı bazı pozitif ayrıcalıklardan yararlanan bu şirketler; inşaat, gıda, perakendecilik, bankacılık, enerji ve diğer bazı sektörlerde faaliyet göstererek bölgenin kalkınmasına önemli katkılarda bulunmuşlardır. Öyle ki, 2010 yılı itibarıyla Irak Kürt bölgesinde satılan malların \% 80'inin Türk menşeli olduğu tespit edilmiştir (Turunc, 2011:44).

Tablo 2: Yıllara Göre IKBY Bölgesindeki Türk Şirket Sayısı

\begin{tabular}{|l|l|}
\hline YIL & IKBY'DEKİ TÜRK ŞİRKET SAYISI \\
\hline 2009 & 485 \\
\hline 2010 & 730 \\
\hline 2012 & 1,023 \\
\hline 2013 & 1,500 \\
\hline
\end{tabular}

Kaynak: (Fidan, 2016: 121) 
2014 yılında merkezi yönetimle yaşanan petrol anlaşmazlığı sonucu Irak Merkezi Yönetiminin IKBY’nin bütçesinde kesintiye gitmesi bölgedeki ekonomik krizi tetikleyen en önemli unsur olmuştur. Bu gelişme, IKBY hükümetinin şirketlerin hakedişlerini ödeyememesiyle sonuçlanarak bölgede yatırım yapan şirketlerin sayısının azalmasına neden olmuştur. Bu gelişmeyi takiben IŞİD’in aynı yılın Haziran ayında Musul'u alarak IKBY sınırlarına yaklaşması ekonomik krizi derinleştirerek birçok yatırımcının bölgeyi terk etmesiyle sonuçlanmıştır. Bölgede ekonomik krize sebep olan bu gelişmelere rağmen IKBY bölgesindeki Türk şirketlerin sayısında ciddi bir azalma olmamıştır. IKBY yetkililerine göre 2015 yılının başları itibarıyla bölgede yatırım yapan Türk şirketi sayısı 1300'ün üzerinde olmuştur (Kuzey Irak’ta 1351 Türk Şirketi,, 2015).

Merkezi hükümetle yaşanan bütçe sorunları ve IŞİD tehdidinin neden olduğu ekonomik krize rağmen 2016 yılı itibarıyla IKBY pazarını yine de Türk şirketleri domine etmiştir. 2500 yabancı şirketin faaliyet gösterdiği IKBY bölgesinde Türk şirketleri yaklaşık 1000 şirketle birinci sırada yer almıştır (Diversification Needed, 2014). Söz konusu şirketler dönemsel ekonomik olumsuzluklara rağmen Türkiye’nin IKBY ile ilişkilerinin sürdürülebilir olmasında önemli rol oynamaya devam etmişlerdir.

Sonuç olarak, 2008 yılından itibaren yükselen ticaret hacmi ve çok sektörlü ekonomik yatırımlar kolaylaştırıcı unsurlar olarak güvenliksizleştirme sürecine önemli katkılarda bulunmuştur. Özellikle Türk şirketlerinin bölgedeki yatırımları bölgenin kalkınmasında bir lokomotif işlevi görmüş ve ekonomik krizlerin etkilerinin azaltılması yönünde önemli katkılar sağlamışlardır. Bu yöndeki çabalar daha sonraki dönemlerde IKBY’nin petrol şirketlerine olan borçlarını \% 25 oranında geri ödemesi gibi olumlu ekonomik sonuçlar doğurmuştur (Kurdistan Region reduces debts to foreign oil companies by $\$ 1$ billion, 2017).

Bölge ekonomisine olumlu yansımaları olan Türk yatırımlarına ek olarak, mevcut ekonomik işbirliğine stratejik ürünlerin de dahil edilmesiyle Türkiye-IKBY arasındaki ilişsiler daha farklı bir boyuta evrilmiştir. Türk yatırımlarının önemli bir yer tuttuğu ekonomik ilişkilerin ana temasını bir süre sonra petrol ve doğalgaz gibi stratejik ürünler oluşturmaya başlamıştır.

Türkiye’nin küresel enerji transit merkezi ve dünyanın en büyük ekonomilerinden birisi olma hedefi ile Irak Kürt Bölgesel Yönetiminin petrol ve doğalgazını uluslararası piyasalara ulaştırma hedeflerinin oluşturduğu asimetrik karşılıklı bağımlılık, iki taraf arasında enerji alanındaki işbirliği ile sonuçlanmış ve bu durum aynı zamanda Türkiye’nin Irak Kürt bölgesine yönelik politikasındaki paradigma değişikliğinde önemli bir rol oynamıştır. Paradigma değişikliği, Türkiye’nin mevcut enerji politikaları ve vizyonu ile yakından ilintilidir.

Bu vizyona paralel olarak Irak enerji pazarına daha fazla angaje olan Türkiye, önceleri Irak Kürt Bölgesel Yönetimi ile yaptığı tüm anlaşmalara Bağdat’ı da dahil etmeye yönelik bir çaba göstermiş, fakat 2011 yılından itibaren önemli bir paradigma değişikliğine 
giderek Irak Kürt bölgesi ile bağımsız ilişkiler kurmaya başlamıştır. Bu paradigma değişikliğinin en önemli nedenlerinden birisi, Türkiye’nin dönemin Irak Başbakanı Nuri El Maliki'nin Irak’ta başta Sünni gruplar olmak üzere toplumun bazı kesimlerini dışlayan yönetim anlayışı ve Maliki’nin Türkiye'yi Irak’ın iç işlerine karışmakla suçlamasından kaynaklanmaktaydı (Charountaki, 2012: 193).

Elbette ki bu paradigma değişikliğinin tek nedeni Maliki’nin otoriter ve dışlayıcı yönetim anlayışı ve Türkiye’ye yönelik suçlayıcı söylemleri değildi. Irak Kürt bölgesinin petrolünü uluslararası pazarlara ulaştırarak Bağdat’ta karşı özerkliğini daha da ileri bir noktaya taşıma hedefi ile Türkiye'nin yeni ekonomik vizyonu çerçevesinde yakın enerji kaynakları için bir transit ülke olma konumunu sürdürme ve petrol-doğalgaz satın aldığı ülkelere karșı potansiyel bir alternatif yaratarak daha bağımsız enerji politikaları olușturabilme kapasitesine ulaşma hedefleriyle simetrik olmayan karşılıklı bir bağımlık oluşturması diğer nedenler arasında gösterilebilir. Dolayısıyla, Türkiye ile Irak Kürt Bölgesel Yönetimi arasındaki ilişkiler bir süre sonra enerji gibi stratejik bir konuya odaklanmıştır.

Irak Kürt Bölgesel Yönetimi bölgesinde 2009'dan itibaren keşfedilen petrol ve doğalgaz miktarı, enerji arzı ve güvenliği bağlamında Türkiye’nin bu bölgeye yönelik politikasının Türkiye’ye fayda-maliyet analizi açısından da önemli potansiyel avantajlar sunabilecek kapasitede olduğu görülmüştür. Ağustos 2009'da Gulf Keystone şirketinin Kürt bölgesinin Türkiye sınırına yakın bir bölgesi olan Şekhan'da keşfettiği yeni petrol rezervi ile birlikte, Irak Kürt Bölgesel Yönetiminin mevcut durumda tahmini 45 milyar varil petrol rezervine sahip olduğu ve bu miktarla dünyanın petrol bakımından en zengin bölgelerinden birisi olduğu ortaya çıkmıştır (Balcı, 2014: 12).

Tablo 3: Irak Kürt Bölgesel Yönetimi Enerji Rakamları (2013)

\begin{tabular}{|l|l|}
\hline Petrol Rezervi & 45 milyar varil \\
\hline Doğalgaz Rezervi & $2.8-5.6$ trilyon metre küp \\
\hline Petrol ve Doğalgaz Yatırımı & $15-20$ milyar dolar \\
\hline Petrol ve Gaz Sahaları & 57 \\
\hline 2013 Petrol Üretimi & 300.000 varil/gün \\
\hline
\end{tabular}

Kaynak: (Balcı, 2014:12)

Türkiye sınırına yakın bölgelerinde yeni rezervlerin keşfedilmesiyle, Irak Kürt Bölgesel Yönetimi'nin sınırları dahilindeki enerji pastası büyük enerji şirketlerinin de ilgisini çekmiştir. Şirketlerin Erbil ile Bağdat’tan bağımsız anlaşmalar imzalaması ve bu bölgedeki enerjiyi dış pazarlara ulaştırma hesapları, Ankara’nın üçüncü ülkelere olan enerji bağımlılı̆̆ını azaltma ve enerji transfer merkezi olma politikalarıyla örtüşmekteydi (Balcı, 2014: 18). 
Buna karşılık, landlocked bir bölge olan Irak Kürt bölgesinin enerji ürünlerini Türkiye üzerinden uluslararası pazarlara ulaştırması bu bölge açısından son derece önemli avantajlar sağlamaktaydı. Irak Kürt Bölgesel Yönetimi, enerji ürünlerini uluslararası pazarlara ulaştırdığı takdirde amaçladığı ekonomik hedefler doğrultusunda güçlü küresel ekonomilerle entegre olacak, bölgesel ve küresel güçlerle kuracağ 1 yakın ekonomik ve siyasi ilişkilerle güvenliğini artıracak ve uluslararası alanda daha fazla tanınırlık elde edecekti (Anaid, 2014: 49).

Türkiye ile Irak Kürt Bölgesel Yönetimi arasında yukarıdaki sebepler bağlamında Türkiye’nin diş politikasındaki paradigma değişikliği sonucu özellikle enerji alanında doğrudan yaptığı işbirliği, Bağdat'ın tüm itirazlarına rağmen devam etmiştir. IKBY ile bağımsız anlaşmalar imzalayan ve bölgede aktif petrol ve doğalgaz çıkarma faaliyetlerinde bulunan uluslararası şirketler göz önüne alındığında, Türkiye’nin bu bölgeyle enerji konulu anlaşmalar yapan ilk ülke olmadığı görülmektedir. Türkiye’nin enerji bağlamındaki söz konusu proaktif politikasının küresel şirketlerle rekabet oluşturduğu söylenebilir.

Önemli küresel enerji şirketlerinden olan Gulf Keystone şirketinin IKBY bölgesinde tespit ettiği petrol rezervinin büyüklüğü, dünyanın önde gelen diğer enerji şirketlerinden olan Exxonmobil, Chevron, Gazprom Neft ve Total'in de ilgisini çekmiş ve bu şirketlerin bölgeye yönelmesine neden olmuştur. Bu şirketler, 2011 yilından başlayarak Erbil ile Bağdat'tan bağımsız çeşitli anlaşmalar yapmıştır (Balc1, 2014: 11). Türkiye, uluslararası büyük enerji şirketlerinin bölgeye yönelik ilgilerinin yoğunlaştığı bir dönemde, kızışan rekabet ortamında bölgedeki enerji anlaşmalarından daha fazla pay almak için çeşitli diplomatik girişimler başlatmış, hem bölgedeki Türk özel girişimlerini destekleyerek hem de bölgede faaliyet gösterecek yeni şirketler kurarak bölgedeki etkin konumunu sürdürmeye çalışmıştır.

Türk ve yabancı şirketlerin Erbil ile Irak Merkezi Yönetiminden bağımsız anlaşmalar imzalaması Bağdat'ın tepkisini çekse de, Bağdat'ın söz konusu şirketlere yaptırım anlamında aldığı önlemler bir sonuç doğurmamıştır. Fakat, daha sonraki süreçte bölgede faaliyet gösteren şirketlerin karşılaştıkları en önemli sorun, bölgede çıkarılan hidrokarbonun dünya pazarlarına nasıl ulaştırılacağı konusu olmuştur. Bu durum, küresel enerji şirketlerini Türkiye’yi hesaba katmak zorunda oldukları yeni arayışlara itmiştir.

Sorunun çözümüne yönelik arayışlar çerçevesinde yapılan müzakere ve görüşmeler neticesinde 2013 yılında gelinen aşama, Türkiye ile IKBY arasında enerji nakil hatlarının inşası konusunda varılan uzlaşı olmuştur. IKBY’nin bu yöndeki talepleri önceleri Ankara’nın IKBY'nin bu konuda Bağdat ile anlaşması şartına bağlansa da, Erbil'in Bağdat ile uzlaşma arayışlarının sürekli olarak sonuçsuz kalması, Türkiye'nin bu konuda doğrudan Erbil'i muhatap alması ile sonuçlanmıştır.

Takip eden süreçte, IKBY ile Türkiye arasındaki petrol boru hattının Eylül 2013'te tamamlanacağı, bölgeden Türkiye'ye doğalgazın da 2016'da ihraç edileceği IKBY üst düzey yöneticileri tarafından açıklanmıştır (Balc1, 2014: 19). Bu konuyla ilgili benzer 
projeksiyonlar, daha sonra IKBY'de faaliyet gösteren en önemli Türk şirketi olan Genel Enerji tarafından da teyit edilmiştir. Şirketin üst düzey bir yetkilisinin İstanbul'da gerçekleştirilen bir kongrede verdiği bilgiye göre, IKBY’nin petrol ihracat kapasitesinin 3 yıl içinde günlük 1 milyon varil olarak hedeflendiği, Türkiye’ye doğalgaz taşıyacak yatırımların da en geç 2018'de tamamlanacağı ifade edilmiştir (Kuzey Irak Gazı En Geç 2018'de Türkiye'de, 2014). Bu taahhütler paralelinde söz konusu petrol boru hattının inşası belirtilen süre içerisinde tamamlanmıştır.

İnşa edilen boru hattıyla bölgeden gelen IKBY kaynaklı petrolün Türkiye'ye taşınması sorunu çözüme kavuşturulmasından sonra, bu defa da Ceyhan'a ulaşan petrolün satışı ile ilgili sorunlar ortaya çıkmıştır. Bağdat yönetiminin IKBY'den doğrudan alınan petrolün üçüncü ülkelere satışı konusunda ikna edilememesi (Balc1, 2014: 20) ve satışı engellemeye yönelik uluslararası platformlarda başlattığı girişimler Türkiye'de depolarda tutulan petrolün satışını bir süre geciktirse de, uluslararası pazarlara ulaştırılmasını engelleyememiştir. Tüm engelleme girişimlerine rağmen, Türkiye'de depolanan petrolün 11.2 milyon varillik kısmının 16 tanker ile 12 Eylül 2014 tarihi itibarıyla uluslararası pazarlara sevk edildiği dönemin Enerji Bakanı Taner Yıldız tarafından ifade edilmiştir (Irak gazı 3 yıl gecikecek, 2014). Petrolün dış piyasalarda satışı sonraki süreçte artarak devam etmiştir. Türkiye'nin Bağdat ile IKBY arasındaki anlaşmazlığa rağmen, tüm bu süreç boyunca, petrolün uluslararası pazarlara ulaşması konusundaki çabaları IKBY tarafından çok olumlu karşılanmış ve IKBY’nin Türkiye’yi “güvenli bir ortak” olarak değerlendirmesine neden olmuştur (Kürtlerden Türkiye’ye Büyük Övgü, 2014).

\section{Şekil 1: Türkiye-IKBY Petrol Boru Hattı}

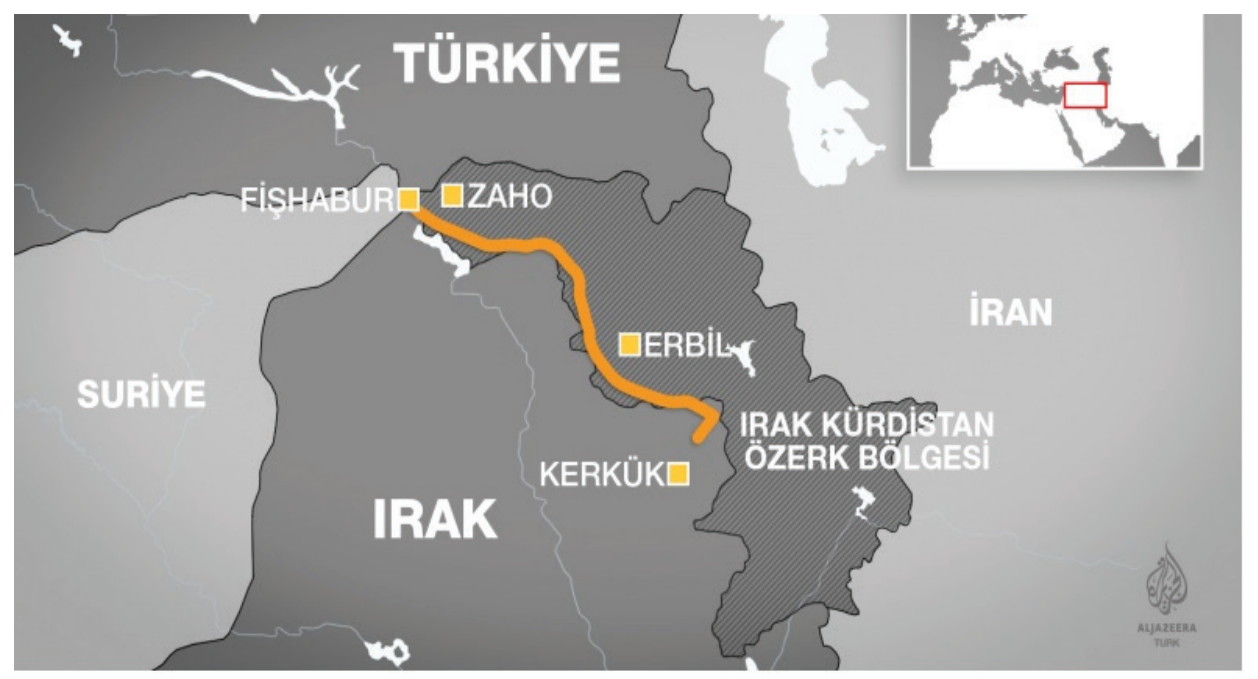

Kaynak: (Kürt Petrolü Uluslararası Piyasalarda, 2014) 


\section{Şekil 2: IKBY'nin 2015 Yilında Türkiye Üzerinden Yaptığı Petrol İhracatı}

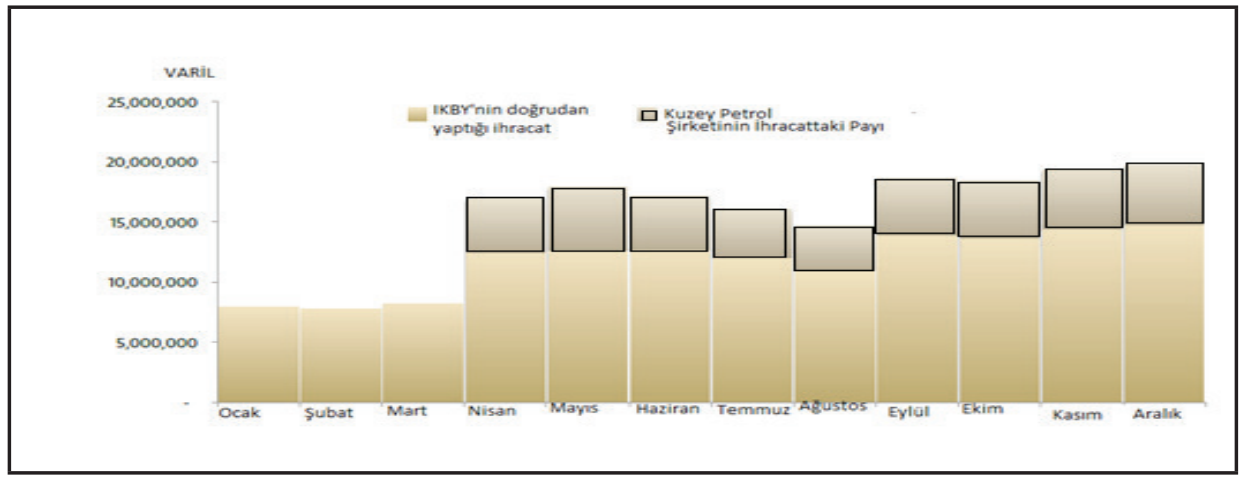

Kaynak : KRG Ministry of natural Resources, 2015)

IKBY’nin Türkiye’yi "güvenli ortak" olarak nitelendirmesinin ne derece doğru olduğu sonraki yıllarda petrol ticaretinin her türlü olumsuzluğa rağmen devam etmesiyle ortaya çıkmıştır. IKBY, hidrokarbon üretimi ve satışı ile ilgili hedeflerine bölgedeki ekonomik kriz ve IŞİD faktöründen dolayı tam olarak ulaşmasa da, 2015 yılında Türkiye üzerinden yaklaşık 180 milyon varil petrol ihraç etmiştir (KRG Ministry of natural Resources, 2015). 2016 yılında ihracat rakamlarında yukarıda belirtilen olumsuzluklardan dolayı bir düşüş olsa da, rakamlarda bir toparlanma süreci başlamıştır. IKBY Doğal Kaynaklar Bakanlığı verilerine göre 2016 yılının Ekim ayında Ceyhan Limanı üzerinden toplam 16 milyon 766 bin 563 varil petrol ihraç edilmiş ve bu sevkiyattan IKBY yaklaşık 417 milyon dolar kar elde etmiştir (IKBY, Türkiye üzerinden 636 milyon dolarlık petrol sattı, 2016).

Tablo 4: 2016 Yılı IKBY Petrol İhracat Rakamları

\begin{tabular}{|l|l|}
\hline $\mathbf{2 0 1 6}$ & İHRACAT (Günlük Varil) \\
\hline Ocak & 453,021 \\
\hline Şubat & 258,746 \\
\hline Mart & 324,712 \\
\hline Nisan & 516,038 \\
\hline Mayıs & 513,041 \\
\hline Haziran & 499,875 \\
\hline Temmuz & 510,813 \\
\hline Ağustos & 448,033 \\
\hline Eylül & 505,421 \\
\hline
\end{tabular}

Kaynak: (KRG Ministry of natural Resources, 2016) 


\subsection{Orta Doğu'da Yeni Gelişmeler ve Türkiye ile IKBY Arasındaki Yeni İşbirliği} Alanlar1

Oyun ve aktörlerin sayıca fazla olduğu ve aynı zamanda dinamik bir bölge olan Orta Doğu'da, 2000'li yılların başında kurulan ve 2014 ortalarında önce Suriye'de daha sonra da Irak’ta öngörülemeyen bir hızla büyüyen IŞİD örgütünün bölge dengelerinde meydana getirdiği değişim, başta örgütün alan hakimiyeti sağladığı Suriye ve Irak olmak üzere bazı bölge ülkelerini önemli oranda etkilemiştir.

Takip eden süreçte ismini İslam Devleti (IDD) olarak değiștiren örgüt, öncelikle Suriye'de muhalif unsurlarla savaşmış, daha sonra da Irak’ta bazı Sünni fraksiyonlarla ortak hareket ederek Musul'u ele geçirmiş, (Gürler ve Özdemir, 2014: 60) ve ağırlıklı olarak Sünni bölgelerinde hakimiyet kurmuştur. Daha çok Sünni bölgelerde hakimiyet alanları kuran örgüt, sonraki süreçte, Irak ordusundan elde ettiği ağır silahlarla bu ülkedeki özellikle Şii ve Kürt unsurları hedef tahtasına yerleştirerek söz konusu grupların meskun olduğu bölgelere saldırılar gerçekleştirmiştir.

IŞID’in Irak’ın kuzeyine yönelik saldırılarında sayıları 30. 000 i bulan Kürt, Türkmen, Hıristiyan, Ezidi ve Şebek göç etmek zorunda kalmış ve bazı stratejik yerler bu örgütün denetimine geçmiştir. IŞíD’in ilerleyişi ile birlikte, bazı etnik ve dini azınlık grupları soykırım tehlikesi ile karşı karşıya kalmış ve militanlar IKBY’nin başkenti Erbil'e 20 km’ye kadar yaklaşmışlardır (Ali, 2014: 1-3). IŞı̇D saldırıları, takip eden süreçte, ABD’nin hava unsurları desteğiyle kısmen durdurulmuş ya da işgal edilen yerlerin bir kısmı geri alınmış olsa da, örgütün bölgede oluşturduğu kaos, iç göç, kargaşa ve istikrarsızlıkların izleri hala devam etmektedir.

Musul'un işgal edilmesinden hemen sonra, henüz IŞİD saldırıları tam anlamıyla IKBY bölgesine ulaşmamışken Türkiye ile IKBY arasındaki bazı temaslar, IŞİD’in iki tarafça da ortak tehdit olarak algılandığını göstermiştir. Bu tehdide karşı, Türkiye-IKBY arasında bazı ortak önlemler alınmıştır. Söz konusu önlemlerin bir parçası olarak, Musul'un işgal edilmesiyle birlikte bu bölgeden Irak Kürdistan bölgesine göç eden Türkmen sığınmacılar IKBY tarafından kabul edilmiş ve bu durum Türkiye’nin takdirini kazanmıştır. Bu konuyla ilgili olarak dönemin Başbakanı Erdoğan, IKBY Başbakanı Neçirvan Barzani’ye bir mektup göndererek, bu tür adımların Türkmen-Kürt kardeşliğini güçlendirdiğini ve ilişkilerin ilerideki süreçte daha da yüksek düzeye çıkarılacağını ifade etmiştir (Durukan, 2014).

IŞID’in Musul'u işgali sırasında Irak ordusunun direnç göstermeyerek tüm ağır silahlarını bırakıp kaçması, Bağdat ile Erbil arasında yeni tartışmaların yaşanmasına neden olmuştur. Türkiye bu konjonktürde, IKBY’nin IŞID tehlikesine karşı önlem almak amacıyla, Kerkük dahil Irak Merkezi Yönetimi ile IKBY arasında statüsü tartışmalı olan bölgelerde tek taraflı hakimiyet sağlamasına, bu bölgelere Peşmergeleri konuşlandırmasına ve IKBY bölgesinin bağımsızlık talebini net bir biçimde dile getirmesine eskiden olduğu kadar sert tepki göstermemiştir. 
IKBY'den bağımsızlık taleplerinin yükseldiği bir dönemde, dönemin AK Parti Sözcüsü Hüseyin Çelik'in Irak’ın bölünmesi ve Irak Kürt bölgesinin bağımsızlı̆̆ını ilan etmesi durumunda, söz konusu bağımsızlık ilanının Türkiye’yi eskisi kadar rahatsız etmeyeceği yönündeki beyanları (Hüseyin Çelik’ten Bağımsız Kürdistan Açılaması, 2014), eskiden Türkiye için kırmızı bir çizgi ve savaş nedeni olarak sayılabilecek IKBY’nin böyle bir girişiminin ilişkilerin güvenliksizleştirilmesi süreciyle artık varoluşsal bir tehdit olarak algılanmadığını göstermiştir. IŞID saldırıları sürecinde Türkiye-IKBY güvenliksizleştirmelerinin sağladığı somut işbirliğinin bir diğer örneği Türkiye’nin eskiden varoluşsal bir tehdit olarak gördüğ̈̈ IKBY'e silah yardımı yapması olmuştur (Türkiye silah verdi, açıklamadık, 2014).

\subsection{Türkiye'nin IKBY İle Eğitim Alanında Normalleşen İlișkileri}

Türkiye ile IKBY arasında güvenliksizleştirilen ilişkilerin eğitim sektörüne de olumlu yansımaları olmuştur. Irak Kürt Bölgesel Yönetimi bölgesindeki bazı üniversiteler, 2000'li yılların başından itibaren özellikle Doğu ve Güneydoğu Anadolu bölgelerinden bazı öğrenciler için üniversite eğitimi için alternatif oluşturmaktaydı. Üstelik öğretim dilinin Kürtçe ve İngilizce olduğu bu üniversiteleri tercih eden Türkiye kökenli öğrencilere belli bir miktar burs da verilmekteydi. Fakat bu üniversitelerde öğrenim gören öğrenciler açısından en büyük sorun, Yüksek Öğretim Kurulunun (YÖK) bu üniversitelerin denkliklerini tanımamasıydı (Şardan, 2005). YÖK denkliğinin tanınması yönündeki talepler, özellikle 2005 yılından başlayarak dile getirilmesine rağmen, bu talepler söz konusu dönemde Türkiye ve IKBY arasındaki soğuk ilişkilerden dolayı Türkiye tarafında olumlu bir karşılık bulmamıştı.

2000'li yılların ikinci yarısından başlayarak Türkiye ile IKBY arasında spill over bir etkiyle farklı alanlara yansıyan olumlu ilişkilerin eğitim alanındaki somut örneği YÖK’ün Ağustos 2013’te aldığ 1 bir kararla Irak Kürt bölgesindeki üniversitelerin denkliğini tanımasıydı. Güvenliksizleştirmelerin eğitim alanına yansımasının en önemli göstergesi olan bu kararla; Kerkük Üniversitesi ile Irak Kürt bölgesindeki Duhok, Salahaddin ve Hawler Medical Üniversitelerinin denkliği Yüksek Öğretim Kurumunca tanındı. YÖK’ün bu diplomaları daha önce tanımamasının nedenlerinden birisi söz konusu üniversitelerin bazılarının verdiği diplomaların üzerinde "Kürdistan” ibaresinin yazılı olmasaydı (YÖK’ten denklik atağ1, 2013).

\section{SONUÇ}

Türkiye-IKBY ilişkilerini 2008-2016 arası dönemini Barry Buzan ve Ole Waever’in Güvenlikleştirme Teorisi çerçevesinde analiz eden bu çalışmayla Türkiye’nin, bu dönemde, sınırları dışındaki gelişmelere bigane kalma yerine bölgedeki gelişmeleri proaktif olarak yönlendirme çabası içinde olduğu sonucuna varılmıştır. Söz konusu yeni yaklaşımla birlikte, Türkiye’nin Orta Doğu bölgesine yönelik geçmişten süregelen yerleşik politika tercihlerinde önemli değişiklikler yapılmıştır. Bu bağlamda, 2008-2016 arası dönemde IKBY ile olan ilişkilerindeki güvenliksizleştirme süreci yeni paradigmayla paralellik 
göstermiștir. Uzun yıllardır süregelen geleneksel politikadan sapma olarak nitelendirilecek güvenlikçi politikaların terk edilmesi öncelikle bazı psikolojik engellerin yıkılması ile başlatılabilmiştir.

Söz konusu psikolojik engellerin bertaraf edilmesi bağlamında daha önce askeri bürokrasiye havale edilen Kuzey Irak bölgesi, sivil bürokrasinin sorumluluk alanına taşınarak IKBY liderleri ve bölgesel yönetimin üst düzey yetkilileriyle kamuoyuna açık alanlarda ve platformlarda doğrudan temaslar kurulmaya başlanmıştır. Takip eden süreçte, diplomatik ilişkilerin düzeyi aşamalı olarak yükseltilerek resmi ziyaretlere evrilmiş ve bu ziyaretlerde kullanılan bazı söz edimleri ile güvenliksizleştirmelerin yolu açılmıştır. Türkiye ile IKBY yöneticileri arasında sağlanan temaslar, mevcut ekonomik ilişkilerin boyutunu da artırarak işbirliğinin başka alanlara da sıçramasına katkıda bulunmuştur.

2008 yılından başlayarak Türkiye ve IKBY arasındaki mevcut ekonomik ilişkilerin düzeyinin yükseltilmesiyle, Türk şirketlerinin Irak Kürt bölgesindeki yatırımları ve bunun bir sonucu olarak başat ekonomik aktör olma konumları daha da güçlendirilmiştir. Takip eden süreçte, petrol ve doğalgaz gibi stratejik ürünlerin de mevcut ekonomik ilişkilere entegre edilmesi, taraflar arasında enerji alanındaki işbirliğini daha üst düzeye çıkarmayı hedefleyen ortak bir stratejik vizyonun oluşmasıyla sonuçlanmıştır.

Bağdat yönetiminin Irak genelinde farklı mezhep gruplarını dışladığı ve Türkiye’yi bölgede emperyal politikalar izlemekle suçladığı bir konjonktürde IKBY ile de petrol ve doğalgaz satışı konusunda uzlaşamaması, IKBY ile Türkiye arasında Bağdat yönetimini devre dışı bırakan enerji anlaşmalarının imzalanmasıyla sonuçlanmıştır. Bölgedeki enerji rekabetine dahil olan Türkiye, birçok uluslararası enerji şirketinin ilgi gösterdiği bu coğrafyada hem Türk petrol şirketlerini desteklemiş hem de ilgili sektörde rekabet edecek şirketler kurmuştur. Bu alandaki işbirliğinin bir diğer dikkate değer somut sonucu, IKBY petrolünün uluslararası pazarlara Türkiye üzerinden arzının sağlanması olmuştur. Bu işbirliğinin güvenliksizleştirme sürecine olumlu yansımaları olmuştur.

Türkiye ve IKBY arasındaki güvenliksizleştirmelerin yansımalarının görüldügü bir diğer alan eğitim sektörü olmuştur. Bu alanda yapılan işbirliği sonucu Yüksek Öğretim Kurulu, daha önce defalarca reddettiği IKBY bölgesindeki üniversitelerin denkliğini tanımış ve Irak Kürt bölgesinden gelen öğrencilerin bazı Türk üniversitelerinde öğrenim görmelerinin önünü açmıştır.

Normalleşen ilişkilerin sağladığı işbirliği ve ortak vizyon, Orta Doğu'da meydana gelen yeni gelişmeler karşısında Türkiye ve IKBY’nin ortak tutumlar sergilemelerine neden olmuştur. Güncel gelişmeler karşısında bu anlamdaki işbirliğinin en somut örneği, IŞİD’in saldırılarından kaçan Türkmenlerin IKBY bölgesinde ağırlanması ve Türkiye’nin IKBY’nin IŞID ile mücadelesinde IKBY’ye silah yardımında bulunmasıdır. Bu süreçte, IKBY’nin IŞID tehlikesine karşı Irak’ta statüsü tartışmalı bazı bölgelerde hakimiyet sağlaması ve bağımsızlık taleplerinde bulunması, eskiden olduğu gibi Türkiye tarafından casus belli olarak değerlendirilmemiştir. Bununla birlikte, Türkiye-IKBY arasında tedricen geliştirilen 
ve normal siyaset alanına taşınarak güvenliksizleştirilen ilişkilerin Türkiye ve IKBY’nin iç siyasetindeki dinamikler bölgesel ve küresel aktörler bağlamında düşünüldüğünde ilişkilerin en iyi olduğu dönemde bile "kırılgan" olma özelliğini sürdürmüştür.

$\mathrm{Bu}$ dönemde, "Güvenliksizleștirici aktörler" olarak tanımlanabilecek dönemin siyasi liderleri ya da yöneticileri yerleşik politikaların dışına çıkarak Iraklı Kürt gruplarla doğrudan, aracısız ve siyaset alanı içinde ilişki kurmaya çalışmıştır. Bu politikanın, dış politika karar alıcılarının "tarihdaşlık" perspektifiyle Türkiye’nin eski Osmanlı tebaası olan halklarla ilişkilerini restore etmesi gerektiği ve ancak böylece bölgesel ve küresel yükselişini gerçekleştirebileceği yönündeki ideallerinin bir sonucu olduğu tespit edilmiştir. Bu bağlamda Türkiye, 2000'li yılların ortalarına kadar varoluşsal tehdit olarak algıladığı Irak Kürt bölgesi ile ilişkilerini yeniden düzenlemiş ve bu bölgenin gerek Bağdat yönetimi ile sorunlar yaşadığı dönemlerde, gerek ekonomik varlıklarını uluslararası pazarlara ulaştırma süreçlerinde en büyük destekçisi olmuştur. 


\section{KAYNAKÇA}

Abacıoğlu, K. (2014). En Değerli Komşumuz Kuzey Irak, Ekonomi Vitrini, 22-27.

Ali, O. (2014). IŞİD’le Savaşın Irak Bölgesel Yönetimindeki Yansımaları, ORSAM Bölgesel Gelişmeler Değerlendirmesi, No. 10, 1-12.

Anaid, A. (2014). Turkish Economic Expansion and its implications, Kurdistan Review Invest in Group, Issue 5, 48-49

Aras, B. ve Polat, K. R. (2008). From Conflict to Cooperation: Desecuritization Of Turkey's Relations with Syria and Iran, Security Dialogue, Vol. 39, No. 5, 495-515.

Balcı, A. (2014). Enerijisine Kavuşan Komşuluk: Türkiye-Kürdistan Bölgesel Yönetimi İlişkileri, Seta Analiz, Sayı 97, 1-26.

Buzan, B. ve Waever, O. (2003). Regions and Powers: The Structure of International Security, New York, Cambridge University Press.

Buzan, B; Waever, O., ve De Wilde, J. (1998). Security: A New Framework for Analysis, Boulder, Lynne Reinner Publisher.

Coşkun, B. B. (2008). Analysing desecuritisations: prospects and problems for IsraeliPalestinian reconciliation, Global Change, PeaceぬSecurity, Vol. 20, No. 3, 393-408.

Coşkun, B. B. (2011). Analysing Desecuritization: The Case of Israeli-Palestinian Peace Education and Water Management, Newcastle, Cambridge Scholars Publishing.

Charountaki, M. (2012). Turkish Foreign Policy and the Kurdistan Regional Government, Perceptions, Vol. XVII, Number 4, 185-208.

Fidan, B. C. (2016). Turkish Business in The Kurdistan Region of Iraq, Turkish Policy Quarterly, Vol. 14, Number 4, 117-126.

Gürler, T. R. ve Özdemir B. Ö. (2014). IŞİD: Irak’ta Yerli, Suriyede Yabanc1, Orta Doğu Analiz, C. 6, S. 63, 58-61.

Hansen, L. (2012). Reconstructing desecuritisation: the normative-political in the Copenhagen School and directions for how to apply it, Review of International Studies, Vol. 38, Issue 3, 525-546.

Kaliber, A. (2005). Türkiye'de Güvenlikleştirilen Bir Alan Olarak Dış Politikayı Yeniden Düşünmek: Kıbrıs Örneği, Uluslararası İlişkiler, C. 2, S. 7, 31-60.

Oelsener, A. (2005). (De)Securitisation Theory and Regional Peace: Some Theoretical Reflections and a Case Study on the Way Stable Peace, EUI RSCAS Working Paper, No. 2005/27, 1-21.

Oran, B. (2013). Türk Dış Politikası:2001-2012, C. 3, İstanbul, İletişim Yayınları.

Özpek, B. B. (2011). Çatışmadan İşbirliğine: Türkiye ve Iraklı Kürtler, Türk Dış Politikası Yıllığı 2010, Ankara, Seta Yayınları, 581-596. 
Turunc, H. (2011). Turkey's Global Strategy: Turkey and Iraq, IDEAS Reports, London School of Economics and Political Science, 40-44.

Vouri, A. J. (2011). How To Do Security With Words : A Grammar of Securitization in People's Republic of China, Yayınlanmamış Akademik Tez, University of Turku, Turku, China.

Waever, O. (1996). European Security Identities, Journal of Common Market Studies, Vol. 34, No. 1, 103-132.

Waever, O. (1998). Securitization and Desecuritization, On Security, (ed.) Ronnie D.Lipschutz, Columbia University Press, 39-69.

Williams, C. M. (1998). Modernity, identity and security: a comment on the 'Copenhagen controversy', Review of International Studies, Vol. 24, Issue 3, 435-439.

Wilkinson, C. (2007). The Copenhagen School on Tour in Kyrgyzstan: Is Securitization Theory Useable Outside Europe, Security Dialogue, Vol. 38, No. 1, 5-24.

\section{INNTERNET KAYNAKLARI}

Davutoğlu, A. (2013). Büyük Restorasyon: Kadimiden Küreselleşmeye Yeni Siyaset Anlayışımız Konferansı, Dicle Üniversitesi, Diyarbakır, http://www.mfa.gov.tr/ disisleri-bakani ahme/ $\mathrm{t}$-davutoglu_nun-diyarbakir-dicle-universitesinde-verdigi-_ buyuk-restorasyon_-kadim/_den-kuresellesmeye-yeni.tr.mfa (Erişim Tarihi: 27.09.2014).

Diversification Needed (2014). Kurdistan Review Invest in Group, Special Issue, s. 42, http:// investingroup.org/files/kurdistan-review-2016-SE.pdf, (Erişim Tarihi: 27.04.2017).

Durukan, N. (2014). Başbakan Erdoğan'dan Barzani'ye Mektup, Milliyet Gazetesi, http:// www.milliyet.com.tr/basbakan-erdogan-dan-barzani-ye/siyaset/detay/1900588/de/ fault.htm, (Erişim Tarihi:11.10.2014).

Hüseyin Çelik’ten Bağımsız Kürdistan Açıklaması, (2014). Cumhuriyet Gazetesi, http:// www.cl umhuriyet.com.tr/haber/turkiye/88209/Huseyin_Celik_ten_bagimsiz_ Kurdistan_aciklamasi.html, (Erişim Tarihi: 11.10.2014).

IKBY, Türkiye üzerinden 636 milyon dolarlık petrol sattı, (2016). Hürriyet Gazetesi, http://ww/ w.hurriyet.com.tr/ikby-turkiye-uzerinden-636-milyon-dolarlik-petrolsatti-40305095, (Erişim Tarihi: 25.04.2017).

Irak gazı 3 yıl gecikecek, (2014). Milliyet Gazetesi, http://www.milliyet.com.tr/- irak-gazi3-yil-gecikecek-/ekonomi/detay/1938933/default.htm, (Erişim Tarihi: 07.10.2014).

KRG Ministry of Natural Resources, (2015). Oil Production, Export, And Consumption Report 2015, s. 6, http://mnr.krg.org/images/pdfs/Production_Report_2015_WEB. pdf, (Erişim Tarihi: 25.04.2017).

KRG Ministry of Natural Resources, (2016). Kurdistan Oil Production January 
2015-September 2016, s.31, http://mnr.krg.org/images/pdfs/Kurdistan_Oil_ Production_Field/_Operator_2015_2016_1.pdf, ( Erişim Tarihi: 28.04.2017).

Kurdistan Region reduces debts to foreign oil companies by $\$ 1$ billion, (2017). Rudaw, http://www.rudaw.net/english/kurdistan/080520174, (Erişim Tarihi: 14.05.2017).

Kuzey Irak Gazı En Geç 2018'de Türkiye'de, (2014). Yeni Şafak Gazetesi, http://www. yenisafa/ k.com.tr/ekonomi/kirak-gazi-en-gec-2018de-turkiyede-685616, (Erişim Tarihi: 02.10.2014).

Kuzey Irak’ta 1351 Türk Şirketi, (2015). Al Jazeera Türk, http://www.aljazeera.com.tr/ha/ ber/kuzey-irakta-1351-turk-sirketi, (Erişim Tarihi: 27.04.2017).

Kürt Petrolü Uluslararası Piyasalarda, (2014). Al Jazeera Turk, http://www.aljazeera.com. tr/ha/ ber/kurt-petrolu-uluslararasi-piyasalarda, (Erişim Tarihi: 26.04.2017).

Kürtlerden Türkiye’ye Büyük Övgü, (2014). Star Gazetesi, http://haber.stargazete/ .com/ ekonomi/kurtlerden-turkiyeye-buyuk-ovgu/haber-935638, (Erişim Tarihi: 07.10. 2014).

Şardan, T. (2005). Barzani Bursuna İlgi, Milliyet Gazetesi, http://www.milliyet.com. tr/2005/11//16/guncel/gun02.html, (Erişim Tarihi: 11.10.2014).

Türkiye Cumhuriyeti Ekonomi Bakanlığı, (2014). Ülkelere Göre Dış Ticaret, http:// www/ .ekonomi.gov.tr/index.cfm?sayfa=7155BE01-D8D3-8566-45208351967592CF, (Erişim Tarihi: 27.09.2014).

Türkiye İstatistik Kurumu, (2017). Ülkelere Göre Yıllık İhracat, www.tuik.gov.tr/PreIstatis/ tikTablo.do?istab_id=1545, (Erişim Tarihi: 26.04.2017).

Türkiye silah verdi, açıklamadık, (2014). Al Jazeere Turk, http://www.aljazeera.com.tr/ haber/t/ urkiye-silah-verdi-aciklamadik, (Erişim Tarihi: 14. 10.2014).

YÖK’ten denklik atağı, (2013). Akşam Gazetesi, http://www.aksam.com.tr/guncel/yoktenden/ klik-atagi-c2/haber-233140, (Erişim Tarihi: 11.10.2014). 